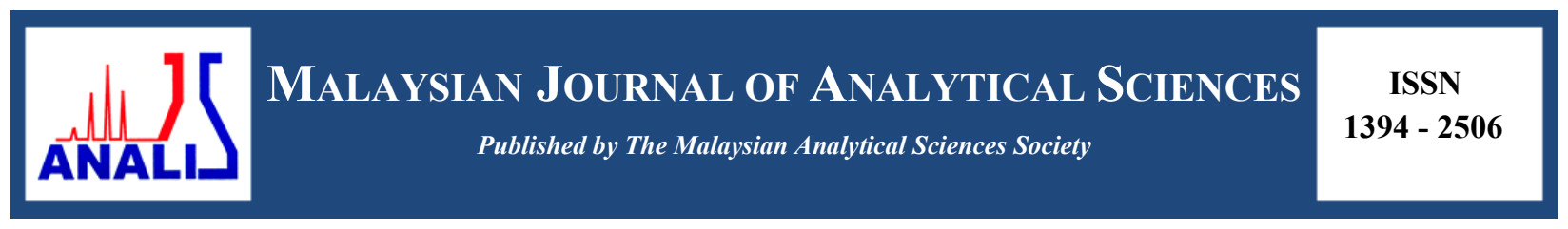

\title{
CHEMICAL AND PHYSICAL CHARACTERIZATION OF OIL PALM EMPTY FRUIT BUNCH
}

\author{
(Pencirian Kimia dan Fizikal Bagi Tandan Kosong Buah Kelapa Sawit) \\ Nurul Suraya Rosli ${ }^{1}$, Shuhaida Harun ${ }^{1,2}$, Jamaliah Md Jahim ${ }^{1,2}$, Rizafizah Othaman ${ }^{3}$ \\ ${ }^{I}$ Department of Chemical and Process Engineering, Faculty of Engineering and Built Environment \\ ${ }^{2}$ Research Centre for Sustainable Process Technology (CESPRO), Faculty of Engineering and Built Environment \\ ${ }^{3}$ School of Chemical Sciences and Food Technology, Faculty of Science and Technology \\ Universiti Kebangsaan Malaysia, 43600 UKM Bangi, Selangor, Malaysia \\ *Corresponding author: harun.shuhaida@ukm.edu.my
}

Received: 21 October 2015; Accepted: 14 June 2016

\begin{abstract}
The interest in Oil Palm Empty Fruit Bunch (OPEFB) as a promising feedstock for bioconversion into value added products is growing fast, thus a thorough analysis of its component becomes necessary. In this study, the biomass chemical composition and physical feature of OPEFB was analysed to explore and understand the potential of OPEFB as bioconversion feedstock. National Renewable Energy Laboratory (NREL) standard protocols were used to characterize and determine the chemical composition of OPEFB. Through this protocol, the structural and non-structural constituents and their compositions were determined based on unextracted and extracted native OPEFB. Structural constituents include the carbohydrate, such as the glucan, xylan and arabinan, and lignin accounted for $31.2 \%, 18.7 \%, 2.7 \%$, and $27.7 \%$, while the non-structural constituents mainly refer to ash and extractives accounted for $0.10 \%$ and $11.87 \%$. In addition, Fourier Transform Infrared Spectroscopy (FTIR) and X-Ray Diffraction (XRD) analysis were also used to further characterize the chemical structure of OPEFB. The FTIR spectral peaks representing the functional groups cellulose, hemicellulose and lignin were observed. Through XRD analysis, the crystallinity index of native OPEFB fiber was calculated around $40 \%$, while it was $37 \%$ for the powder form OPEFB. Nevertheless, the physical feature or surface morphology of the OPEFB fiber has been study by using Scanning Electron Microscopy (SEM). It shows a rigid strand's surface and the presence of silica bodies which commonly found in woody plant.
\end{abstract}

Keywords: lignocellulose, composition, morphology, spectroscopy, crystallinity

\begin{abstract}
Abstrak
Minat terhadap tandan kosong buah kelapa sawit (OPEFB) sebagai bahan mentah secara penukaran bio telah menjanjikan hasil produk tambah nilai yang berkembang pesat, oleh itu suatu analisis yang menyeluruh komponennya menjadi keperluan. Dalam kajian ini, komposisi kimia biomas dan ciri-ciri fizikal OPEFB dianalisis untuk meneroka dan memahami potensi OPEFB sebagai bahan mentah untuk penukaran bio. Protokol piawai National Renewable Energy Laboratory (NREL) telah digunakan untuk mencirikan dan menentukan komposisi kimia OPEFB. Melalui protokol ini, juzuk struktur atau bukan struktur dan komposisi mereka telah ditentukan. Juzuk struktur termasuk karbohidrat, seperti glukan, xilan dan arabinan dan lignin menyumbang kepada $31.2 \%, 18.7 \%, 2.7 \%$, dan $27.7 \%$, manakala juzuk bukan struktur terutamanya merujuk kepada abu dan ekstraktif menyumbang kepada $0.10 \%$ and $11.87 \%$. Di samping itu, analisis Spektroskopi Inframerah Transformasi Fourier (FTIR) dan belauan sinar-X (XRD) juga digunakan untuk mencirikan lagi struktur kimia OPEFB. Puncak spektrum FTIR yang mewakili kumpulan berfungsi daripada selulosa, hemiselulosa dan lignin telah diperhatikan. Melalui analisis XRD, indeks penghabluran gentian OPEFB asli dikira sekitar 40\%, manakala ia adalah 37\% untuk OPEFB berbentuk serbuk. Walau bagaimanapun, ciri atau permukaan fizikal morfologi serat OPEFB asli yang telah dikaji dengan menggunakan Mikroskopi Imbasan Elektron (SEM). Ia menunjukkan permukaan helaian yang tegar dan kehadiran badan-badan silika yang biasa ditemui dalam tumbuhan berkayu.
\end{abstract}


Kata kunci: lignoselulosa, komposisi, morfologi, spektroskopi, penghabluran

\section{Introduction}

In the recent year, there are more than 5000000 hectares' oil palm are cultivated in Malaysia, making the country world's largest exporter of palm oil. As one of the leading producer and exporters of palm oil products, the palm oil industry in Malaysia collectively generate massive amount of oil palm lignocellulosic biomass waste, with oil palm empty fruit bunch (OPEFB) accounting about 16 million tons per year [1].

The OPEFB have traditionally been burnt in incinerator of palm oil mill and their ash recycled into the plantation as fertilizer. However, due to the environmental problem, the incineration of OPEFB has been discouraged [2]. In order to protect the environment and to ensure the sustainability of the oil palm industry, the lignocellulosic biomass waste must be fully exploited.

The building block of native OPEFB fiber is made up from a complex matrix of three main polymers which are cellulose, hemicellulose and lignin. It composed approximately around $44.2 \%$ cellulose, $33.5 \%$ hemicellulose and $20.4 \%$ of the lignin [3]. It also reported that OPEFB is composed $32.9 \%$ glucan, $22.4 \%$ xylan and $1.4 \%$ arabinan [4]. The lignocellulosic material from OPEFB has been considered as a very good source of fermentable sugar for conversion into value added products [5-7]. Cellulose and hemicellulose can be hydrolysed chemically by acid or enzymatically into glucose and a variety of pentose and hexose sugars, which can then be fermented to produce bioethanol.

The investigation on the potential utilization of OPEFB fiber as renewable bioresource require a comprehensive chemical and physical characterization of the biomass. Therefore, the objectives of this study were to examine the surface morphology of OPEFB and quantity of major and minor component of native OPEFB fiber with the aim to utilize them as raw material for biorefinery.

\section{Raw material}

\section{Materials and Methods}

The OPEFB used in this study was collected from Seri Ulu Langat's Palm Oil Milling Factory, Dengkil Selangor with initial moisture content of 55\%. The OPEFB was then sun-dried for 72 hours until the moisture content reached less than 10\%, and then grounded into approximately $2 \mathrm{~mm}$ particle size using a mill (Fritsch GmBH, Germany). The grounded OPEFB were packed in a sealed bag and stored at $-40^{\circ} \mathrm{C}$.

\section{Compositional analysis}

The chemical analysis of native OPEFB fiber was carried out using National Renewable Energy Laboratory (NREL) standard biomass analytical procedure with 3 replication. Moisture content analysis was carried out using moisture analyser (Denver Instrument, Germany), while the ash analysis was conducted using a furnace at $575^{\circ} \mathrm{C}$ for 24 hours [9].

\section{Extractive analysis}

The total extractive determination was carried out with water for 8 hours followed with the $95 \%$ ethanol for 8 hours in a soxhlet extractor. The ethanol soluble material and water soluble material such as non-structural sugar, nitrogenous compound, inorganic compound and waxes were removed during the two-stage extraction process [10]. Non-structural materials must be removed from the biomass prior to analysis to prevent the inteferences.

\section{Carbohydrates and lignin analysis}

The extractive-free sample were hydrolyzed using sequential acid hydrolysis procedure utilizing $72 \%$ sulphuric acid at $30{ }^{\circ} \mathrm{C}$ for an hour and followed by $4 \%$ sulphuric acid at $121^{\circ} \mathrm{C}$ for an hour [11] [12]. The hydrolyzate was filtered and analyzed for monosaccharides using high performance liquid chromatography (HPLC) (Dionex Ultimate 3000, Thermo Scientific, USA) equipped with refractive index detector (RI) and Rezex Phenomex Monosaccharide column (RPM). The hydrolyzate samples and standards were analyzed at $60{ }^{\circ} \mathrm{C}$ with the flowrate of $0.6 \mathrm{ml} / \mathrm{min}$ and 
$20 \mu \mathrm{L}$ injection volume [13]. Post-hydrolysis analyses of the liquid sample from water extraction were also done to quantify the oligomeric sugar. The insoluble portion filtered from the acid hydrolysis process were dried for overnight in a desiccator and were regard as acid insoluble lignin. The filtrate will then quantified spectrophotometrically at $320 \mathrm{~nm}$ using $1 \mathrm{~cm}$ pathlength cuvette for acid soluble lignin.

\section{Morphology study}

Scanning electron microscopy (SEM) analysis was conducted to view the surface structure of native OPEFB fiber. The freeze-dried sample was prepared by sputter-coated with gold prior to imaging with SEM with magnification power of 100 to $2000 \mathrm{x}$.

\section{Spectroscopy characterization}

Fourier Transform Infrared spectroscopy (FTIR) analysis was performed to detect the functional groups presence in the cellulose, hemicellulose and lignin portion of the native OPEFB fiber. FTIR spectra were obtained using a $\mathrm{KBr}$ disc containing grounded sample. The sample were scan from 4000 to $400 \mathrm{~cm}^{-1}$ with resolution of $4 \mathrm{~cm}^{-1}$.

\section{Crystallinity study}

The crystallinity of cellulose in the native OPEFB were studied using X-ray diffraction (XRD) profile. The sample

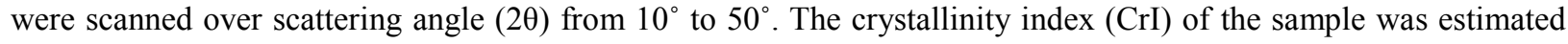
by using equation (1) as follows [14]:

$$
\operatorname{CrI}=\left[\frac{I_{002}-I_{a m}}{I_{002}}\right] \times 100
$$

where, $I_{002}$ is the highest peak intensity of crystalline fractions and $I_{\mathrm{am}}$ define as the low intensity peak at the amorphous region.

\section{Compositional analysis}

\section{Results and Discussion}

The purpose of this part of the paper was to study the composition of native OPEFB fiber for utilizing them as raw material for production of value-added product. The composition of native OPEFB fiber were analyzed for structural carbohydrates, lignin, ash and extractives content. The compositional analyses of native OPEFB fiber were made based native-overall unextracted OPEFB, extractive-free OPEFB, and corrected native-whole OPEFB as presented in Table 1. These results were expressed as the percentage of the oven-dried, native whole unextracted OPEFB.

Since woody lignocellulosic biomass, such as OPEFB contain high amount of extractives which influence the compositional analyses of structural and non-structural constituents, the native-whole unextracted and solventextracted OPEFB were both analysed for the purposes comparing the composition of major constituents, determining the extractable non-structural constituents in the OPEFB, and finally making the appropriate corrections in the composition of particular constituents [15]. Characterization of native-whole unextracted OPEFB only, can be considered inaccurate because the hydrophobic extractives such as oil and waxes inhibit the penetration of sulphuric acid into the biomass causing incomplete hydrolysis thus affecting the analyses for structural carbohydrates [10]. While expressing the result in extractive free basis, also does not allow direct comparison between compositions of the extracted and unextracted materials, since removal of the extractives changes the composition of the constituents in the biomass [8]. Thus, in this study the identified constituents in the extractives were used to correct and convert the composition of the extractives-free OPEFB, from native-whole unextracted basis to the corrected native-whole OPEFB basis.

The structural carbohydrates are the major constituents that made-up structure of lignocellulosic biomass of OPEFB, varied from $57.9 \%$ in the native-whole unextracted OPEFB to $51.5 \%$ in the extractive-free OPEFB. This yielded about $6.4 \%$ reduction in the structural carbohydrates after the extraction which mainly composed of glucan and xylan with a small amount of arabinan. The compositions of these carbohydrate constituents between the native-whole unextracted and the extractive-free OPEFB differed respectively from $35.0 \%$ to $30.9 \%$ for glucan, from $20.3 \%$ to $18.2 \%$ for xylan and from $3.10 \%$ to $2.46 \%$ for arabinan. The arabinan has shown the largest composition difference, with a $21 \%$ reduction, and followed by glucan and xylan with $11 \%$ and $10 \%$ reduction 
respectively. The removal of extractive also reduced the lignin content from $34.9 \%$ in the native-whole unextracted OPEFB to $27.5 \%$ in the extractive-free OPEFB. This shows that the extractives contained approximately around $21 \%$ of lignin, while the other $79 \%$ was still intact in the extractive-free OPEFB fiber. High lignin content in nativewhole unextracted OPEFB was due to the presence of extractives which resulted in falsely high lignin values when unhydrolyzed carbohydrates condense with acid insoluble lignin.

Table 1. Composition of native-whole unextracted, extractive-free and corrected native-whole of OPEFB fiber

\begin{tabular}{|c|c|c|c|}
\hline \multirow[t]{2}{*}{ Constituents } & \multicolumn{3}{|c|}{$\begin{array}{c}\text { Composition of OPEFB (results expressed as a percentage of the } \\
\text { oven-dried, native-whole unextracted OPEFB) }\end{array}$} \\
\hline & $\begin{array}{l}\text { Native-whole } \\
\text { Unextracted } \\
\text { OPEFB }\end{array}$ & $\begin{array}{l}\text { Extractive-free } \\
\text { OPEFB }\end{array}$ & $\begin{array}{l}\text { Corrected Native- } \\
\text { whole OPEFB }\end{array}$ \\
\hline \multicolumn{4}{|l|}{ 1. Structural Constituent } \\
\hline Structural carbohydrates & $57.9 \pm 2.46$ & $51.5 \pm 1.40$ & $52.6 \pm 1.40$ \\
\hline Glucan & $34.6 \pm 2.39$ & $30.9 \pm 1.40$ & $31.2 \pm 1.35$ \\
\hline Xylan & $20.3 \pm 0.05$ & $18.2 \pm 0.40$ & $18.7 \pm 0.39$ \\
\hline Arabinan & $3.10 \pm 0.02$ & $2.46 \pm 0.05$ & $2.7 \pm 0.06$ \\
\hline Total Lignin & $35.0 \pm 2.18$ & $27.7 \pm 0.68$ & $27.7 \pm 0.68$ \\
\hline Acid Insoluble Lignin & $28.00 \pm 1.94$ & $22.07 \pm 0.69$ & $22.07 \pm 0.69$ \\
\hline Acid Soluble Lignin & $7.07 \pm 0.74$ & $5.65 \pm 0.04$ & $5.65 \pm 0.04$ \\
\hline \multicolumn{4}{|l|}{ 2. Non-structural Constituent } \\
\hline Ash & $0.40 \pm 0.01$ & $0.10 \pm 0.01$ & $0.10 \pm 0.01$ \\
\hline Total Extractives & NR & $12.9 \pm 2.25$ & $11.87 \pm 2.25$ \\
\hline Identified Water Extractives & NR & $1.06 \pm 0.09$ & $0.06 \pm 0.07$ \\
\hline Glucose Oligo & NR & $0.24 \pm 0.03$ & NR \\
\hline Xylose Oligo & NR & $0.43 \pm 0.03$ & NR \\
\hline Arabinose Oligo & NR & $0.25 \pm 0.01$ & NR \\
\hline Sucrose & NR & $0.06 \pm 0.07$ & $0.06 \pm 0.07$ \\
\hline Glucose & NR & $0.02 \pm 0.01$ & NR \\
\hline Xylose & NR & $0.07 \pm 0.004$ & NR \\
\hline Ethanol Extractives & NR & $2.32 \pm 0.17$ & $2.32 \pm 0.17$ \\
\hline Other Extractives & NR & $9.49 \pm 2.75$ & $9.49 \pm 2.75$ \\
\hline 3. Moisture content & $9.51 \pm 1.46$ & $9.51 \pm 1.46$ & $9.51 \pm 1.46$ \\
\hline Total Composition & 102.81 & 101.71 & 101.78 \\
\hline
\end{tabular}

All values are mean of duplicate \pm standard deviation, $\mathrm{NR}=$ Not Relevant

In the non-structural constituent, the ash was greatly affected by the extraction process. The ash content decreased from $0.4 \%$ in the native-whole unextracted OPEFB to $0.1 \%$ in the extractive-free OPEFB. This indicates that the extractive-free OPEFB contained approximately only $25 \%$ of the ash content with the remaining $75 \%$ have been solubilize during the two-stage extraction process. The number of extractives for extractive-free OPEFB basis were accounted around $12.9 \%$ which made up of water and ethanol soluble constituents and other extractives. The other extractives composition maybe contains acetyl group, protein content, soluble ash, soluble lignin and many unidentified constituents. As reported in Table 1 the highest compositional content for corrected native-whole 
OPEFB, was for the glucan component followed by xylan and arabinan with $31.2 \%, 18.7 \%$ and $2.7 \%$. The amount of structural carbohydrate of corrected native-whole OPEFB were slightly higher than extractive-free OPEFB because the measured soluble sugar except sucrose in the extractives of the extractive-free OPEFB basis, have been used to correct the compositions of structural carbohydrate. These reduce the number of extractives for corrected native-whole OPEFB to $11.87 \%$ which is $92 \%$ of the total extractives from extractives-free OPEFB basis. The amount accounted for extractives in corrected native-whole OPEFB in this study is still high since many of its constituents such as soluble ash and lignin have not been measured properly. The lignin content of OPEFB fiber in this study is considered high as its make up more than half of the carbohydrates composition and hence the pretreatment step must be applied to the OPEFB to overcome the recalcitrance nature of this biomass for further used as the source of fermentable sugar. The lignin level was also comparable to the lignin content of hardwood. The composition of structural and non-structural constituents of corrected native-whole OPEFB fiber in this work was comparable to the previous studies as shows in Table 2.

Table 2. Composition of extractive-free OPEFB fiber from previous works

\begin{tabular}{lcc}
\hline Constituents & This Study & Hassan et al. [1] \\
\hline Structural Constituent & & \\
$\quad$ Glucan & $31.2 \pm 1.35$ & $36.1 \pm 4.80$ \\
Xylan & $18.7 \pm 0.39$ & $22.4 \pm 2.17$ \\
Arabinan & $2.7 \pm 0.06$ & NA \\
Lignin & $27.7 \pm 0.68$ & $26.5 \pm 2.91$ \\
Non-structural Constituent & & \\
$\quad$ Ash & $0.10 \pm 0.01$ & $2.93 \pm 0.27$ \\
Extractives & $11.87 \pm 2.25$ & $12.74 \pm 0.96$ \\
\hline
\end{tabular}

$\mathrm{NA}=$ Not Available

\section{Morphology analysis}

Figure 1a and $\mathrm{b}$ illustrate the SEM images for the surface structure of native OPEFB fiber with different magnification. The native OPEFB fiber had a rigid surface with a layer of matrix material like lignin or waxes that covered the whole surface of the fiber. This layer might be the protective layer present in most plants to prevent water loss. The cell walls of this biomass are thicker than the hardwood which result in high coarseness and rigidity index as reported by previous studies [16].

Moreover, there are great numbers of silica bodies found embedded on the surface of the fiber strands as highlighted in the Figure 1a and $\mathrm{b}$. The silica bodies are attach to circular craters which are spread uniformly over the strand's surface. In addition to cellulose, hemicellulose and lignin, OPEFB is also rich in inorganic elements such as silica and metal ions [17]. The main constituents present in the silica bodies are silicon and oxygen as reported by the previous works [18]. Silica bodies are the most often mineral found on the surface of woody plants, formed by the invasion and hardening of soil minerals into sedimentary cavities between and within cell wall during plant growth [19]. The surface recalcitrance of the native OPEFB fiber serves as a major physical barrier for enzymatic hydrolysis process due to the difficulty in penetrating the surface to access the cellulose and hemicellulose for sugar production. 

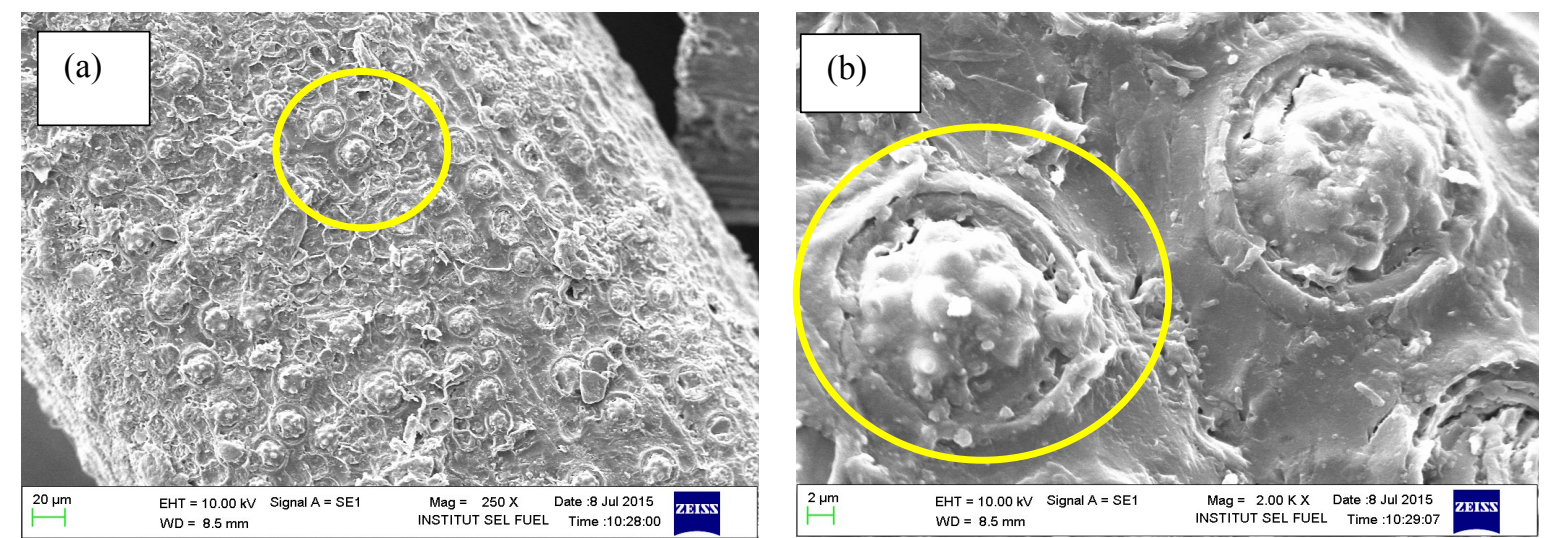

Figure 1. SEM images (a) and (b) of native OPEFB fiber at different magnification (200x; 2000x)

\section{Spectroscopy analysis}

FTIR spectroscopy was used to investigate the functional group presence in the native OPEFB fiber. Figure 2 shows the FTIR spectra of native OPEFB fiber. A strong and broad absorption was observed at a wavenumber of $3355 \mathrm{~cm}^{-1}$ which is related to the stretching of H-bonded in hydroxyl group of cellulose, respectively [20]. The other prominent one around wavenumber of $2900 \mathrm{~cm}^{-1}$ is due to the $\mathrm{C}-\mathrm{H}$ stretching of $\mathrm{CH}_{2}$ from the $\mathrm{CH}_{2}-\mathrm{OH}$ group in cellulose [21]. In addition, the area of 1800 to $600 \mathrm{~cm}^{-1}$ is called the fingerprint area of spectra which has many sharp and well defined absorption bands due to the various functional groups presence in each component of OPEFB. The distinctive bands in the fingerprint region and the components to which these peaks are shown in Table 3.

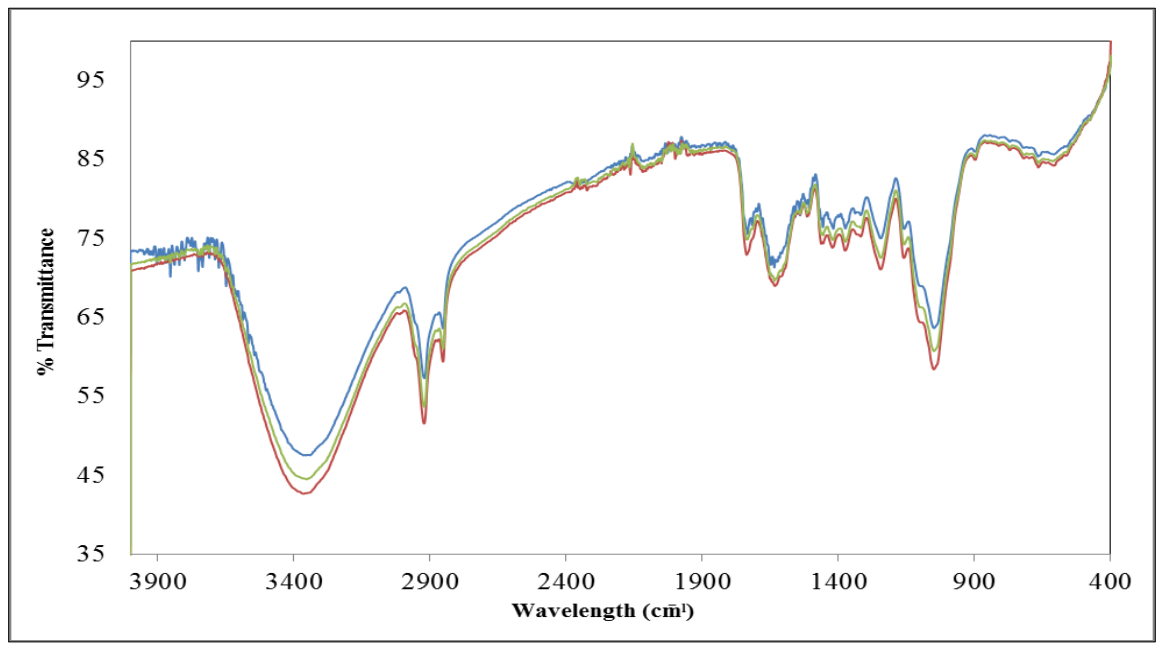

Figure 2. FTIR spectra of native OPEFB

The peak at around wavenumber of $1733 \mathrm{~cm}^{-1}$ can be seen from the spectra, which occur due to the $\mathrm{C}=\mathrm{O}$ stretching of the acetyl and uronic ester groups of the hemicellulose ester. The peak also represents the carbonyl ester linkages of the carboxylic groups of ferulic and p-coumaric monomeric lignin [22]. The peak at $1635 \mathrm{~cm}^{-1}$ was correspond to the bending vibration of the hydroxyl groups of cellulose. Sun and Cheng also reported that the band around 1600 $\mathrm{cm}^{-1}$ was probably due to the bending mode of water, since hemicelluloses have strong affinity for water [23]. The 
absorption band 1244 and $1541 \mathrm{~cm}^{-1}$ are arise mostly from aromatic ring of lignin, while the band around 1635 , 1375,1049 and $667 \mathrm{~cm}^{-1}$ are mainly due to carbohydrates and have no significant contribution from the lignin [24].

Table 3. FTIR wavenumber characterization of native OPEFB [20-27]

\begin{tabular}{ll}
\hline $\begin{array}{l}\text { Wavenumber } \\
\left(\mathbf{c m}^{-1}\right)\end{array}$ & Compound \\
\hline 3355 & O-H stretching \\
$2850-2920$ & C-H stretching in methyl and methylene group \\
1733 & C=O stretching in unconjugated ketones, carbonyl and in ester groups \\
1635 & O-H bending \\
1541 & C=C stretching from aromatic ring of lignin \\
1375 & C-H bending in cellulose and hemicellulose \\
1244 & C-O-C stretching of aryl-alkyl ether \\
1049 & Aromatic C-H in plane deformation-O deformation in primary alcohol \\
667 & C-O out of plane bending mode \\
\hline
\end{tabular}

\section{Crystallinity analysis}

The degree of cellulose crystallinity is a major factor in investigating the potential of OPEFB as the feedstock for bioconversion due to its effects on the enzymatic hydrolysis process as low crystallinity of cellulose increase the efficiency of cellulose hydrolysis by cellulase. Figure 3 shows the X-ray diffractogram of native OPEFB fiber and powder resulted from grinding process with particle size measured as less $250 \mu \mathrm{m}$.

By comparing with the cellulose standard available in the database of XRD system, two main peaks were observed from the XRD patterns at $2 \theta=22.5$ and $2 \theta=16$ representing peak $\mathrm{I}_{002}$ and $\mathrm{I}_{011}$, respectively. As in figure 3 , peak $\mathrm{I}_{011}$ for both samples are corresponding to the amorphous region of hemicellulose and lignin while peaks $\mathrm{I}_{002}$ represent the crystalline region of cellulose [22]. The crystallinity index of native OPEFB fibers were calculated as $40 \%$, while for the powder form of OPEFB fiber with particle size less than $250 \mu \mathrm{m}$ was $37 \%$. Slight decrease in the crystallinity shows that smaller particle size cause decrease in the cellulose crystallinity of the fiber as reported by Sun \& Cheng [23]. The X-ray diffractogram of the fiber and powder form of native OPEFB were also found to be comparable with the X-ray diffractogram of SigmaCell cellulose type 20 from the previous work [1].

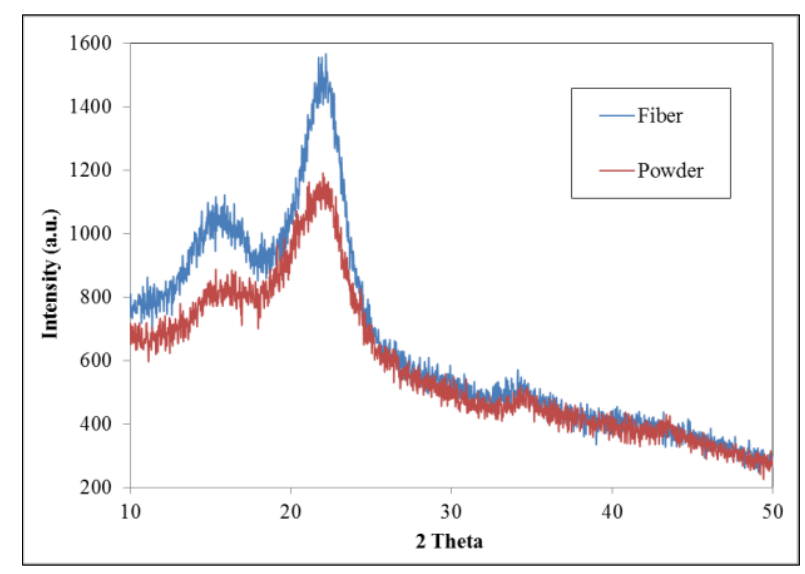


Figure 3. X-ray diffractogram of fiber and powder form of native OPEFB

\section{Conclusion}

In the present study, it was found that the OPEFB fiber were made up of $31.4 \%$ of glucan, $18.6 \%$ xylan and $2.7 \%$ arabinan with the lignin accounted around $23,9 \%$. As for non-structural constituents of OPEFB fiber, the ash and extractive content was around $0.1 \%$ and $8.18 \%$. The morphological study by SEM shows the surface structure of OPEFB fiber is mainly consist of silica bodies. Spectroscopic analysis by FTIR shows a comparable result indicated the presence of the cellulose, hemicellulose and lignin in the fiber. While XRD analysis indicated the crystalline nature of cellulose in the native OPEFB fiber through the (200) peak at $2 \theta=22.5$. OPEFB fiber has the potential as the low-cost feedstock for bioconversion as it contains the polymer of carbohydrates such as cellulose and hemicellulose but due to the surface morphology, crystallinity nature of its element, and the present of lignin, the process required a preliminary pretreatment step to optimize the production of fermentable sugar.

\section{Acknowledgement}

The authors would like to acknowledge Ministry of Education Malaysia and Universiti Kebangsaan Malaysia for the financial and technical support of this research under grant LRGS/2013/UKM-UKM/PT/01.

\section{References}

1. Hassan, O., Tang, P. L., Maskat, M. Y., Md. Illias, R., Badri, K., Jahim, J. and Mahadi, N. M. (2013). Optimization of pretreatments for the hydrolysis of oil palm empty fruit bunch fiber (EFBF) using enzyme mixtures. Biomass and Bioenergy, 56: 137 - 146.

2. Rahman, S. H., Choudhury, J. P., Ahmad, A. I. and Kamaruddin, A. H. (2007). Optimization studies on acid hydrolysis of oil palm empty fruit bunch fiber for production of xylose. Bioresource Technology, 98: 554 559.

3. Astimar, A. A., Husin, M. and Anis, M. (2002). Preparation of cellulose from oil palm empty fruit bunches via ethanol digestion: Effect of acid and alkali catalyst. Journal of Oil Palm Research, 14: 9 - 14.

4. Ming, J. L., Ming, W. L., Gunawan, C. and Dale, B. (2010). Ammonia fiber expansion (AFEX) pretreatment, enzymatic hydrolysis, and fermentation on empty palm fruit bunch fiber (EFBF) for cellulosic ethanol production. Applied Biochemical Biotechnology, 162: 1847 -1857.

5. Hamzah, F., Idris, A. and Tan, K. S. (2011). Preliminary study on enzymatic hydrolysis of treated oil palm (Elaeis) empty fruit bunches fibre (EFB) by using combination of cellulase and beta-1,4 glucosidase. Biomass and Bioenergy, 35: $1055-1059$.

6. Shuit, S. H., Tan, K. T., Lee, K. T. and Kamaruddin, A. H. (2009). Oil palm biomass as a sustainable energy source: A Malaysian case study. Energy, 34(9): 1225 - 1235.

7. Sulaiman, M. A., Abdullah, N., Gerhauser, H. and Shariff, A. (2011). An outlook of Malaysian energy, oil palm industry and its utilization of wastes as useful resource. Biomass Bioenergy, 35: 3775 - 3786.

8. Hames, B. R., Scarlata, C., Sluiter, A., Sluiter, J. and Templeton, D. (2008). Preparation of sample for compositional analysis: Laboratory analytical procedures $(L A P)$. Colorado, United State: National Renewable Energy Laboratory.

9. Sluiter, A., Hames, B., Ruiz, R., Scarlata, C., Sluiter, J. and Templeton, D. (2005). Determine of ash in biomass: Laboratory analytical procedures $(L A P)$. Colorado, United States: National Renewable Energy Laboratory.

10. Sluiter, A., Ruiz, R., Scarlata, C., Sluiter, J. and Templeton, D. (2008). Determination of extractives in biomass. Golden, Colorado: National Renewable Energy Laboratory.

11. Sluiter, A., Hames, B., Ruiz, R., Scarlata, C., Sluiter, J., Templeton, D. and Crocker, D. (2008). Determination of structural carbohydrates and lignin in biomass. Golden Colorado: National Renewable Energy Laboratory.

12. Sluiter, J. B., Ruiz, R. O., Scarlata, C. J., Sluiter, A. D. and Templeton, D. W. (2010). Compositional analysis of lignocellulosic feedstock: Review and description of methods. Journal of Agricultural Food Chemistry, 58(16): $9043-9053$.

13. Abdul, P. M., Harun, S., Md. Jahim, J., Markom, M. and Hassan, O. (2011). Effect of column's temperature and evaluation of RID and ELSD as a suitable ion exchange HPLC detection method of simple sugars. Journal of Science and Technology, 49(58): $599-604$.

14. Segal, L., Creely, J. J., Martin, A. E. and Conrad, C. M. (1959). An empirical method for estimating the degree 
of crystallinity of native cellulose using the X-ray diffractometer. Textile Research Journal, 29(10): 786 - 794.

15. Thammasouk, K., Tandjo, D. and Penner, M. H. (1997). Influence of Extractives on the Analysis of Herbaceous Biomass. Journal of Agricultural and Food Chemistry, 45(2): 437 - 443.

16. Law, K. N. and Jiang, X. (2001). Comparative papermaking properties of oil-palm empty fruit bunch. Tappi Journal, 84: 1 - 13 .

17. Law, K. N., Daud, W. W. and Ghazali, A. (2007). Morphology and chemical nature of fiber strands of oil palm empty fruit bunch (OPEFB). Bioresources, 2: $351-362$.

18. Lins, U., Barros, C. F., Da Cunha, M. and Miguens, F. C. (2002). Structure, morphology and composition of silicon biocomposites in the palm tree Syagrus coronata (Mart.) Becc. Protoplasma, 220: 89 - 96.

19. Yoon, C. J. and Kim, K. W. (2008). Anatomical descriptions of silicified woods from madagascar and indonesia by scanning electron microscopy. Micron, 39(7): $815-831$.

20. Khalil, H. S., Ismail, H., Rozman, H. D. and Ahmad, M. N. (2001). The effect of acetylation on interfacial shear strength between plant fibres and various matrices. European Polymer Journal, 37(5): 1037 - 1045.

21. Xiao, X., Bian, J., Li, M. F., Xu, H., Xiao, B. and Sun, R. C. (2014). Enhanced enzymatic hydrolysis of bamboo (Dendrocalamus gigantus munro) culm by hydrothermal pretreatment. Bioresource Technology, 159: $41-47$.

22. Nazir, M. S., Wahjoedi, B. A., Yussof, A. W. and Abdullah, M. A. (2013). Eco-friendly extraction and characterization from oil palm empty fruit bunch. BioResources, 8(2): $2161-2172$.

23. Sun, Y. and Cheng, J. (2002). Hydrolysis of lignocellulosic materials for ethanol production: A review. Bioresource Technology, 83: $1-11$.

24. Ching, Y. C. and Ng, T. S. (2014). Effect of preparation conditions on cellulose from oil palm empty fruit bunch fiber. Bioresource Technology, 9(4): $6373-6385$.

25. Nomanbhay, S. M., Hussain, R. and Palanisamy, K. (2013). Microwave-assisted alkaline pretreatment and microwave assisted enzymatic saccharification of oil palm empty fruit bunch fiber for enhanced fermentable sugar yield. Journal of Sustainable Bioenergy System, 3: 7 - 17.

26. Pandey, K. K. (1999). A study of chemical of soft and hardwood and wood polymers by FTIR spectroscopy. Journal of Applied Polymer, 71: 1969 - 1975.

27. Kargarzadeh, H., Ahmad, I., Abdullah, I., Dufresne, A., Zainudin, S. and Sheltami, R. (2012). Effects of hydrolysis conditions on the morphology, crystallinity, and thermal stability of cellulose nanocrystals extracted from kenaf bast fibers. Cellulose, 19(3): $855-866$. 